\title{
Acute mesenteric ischemia caused by floating thrombus of the descending thoracic aorta - case report
}

\author{
Ernest Biroš, Robert Staffa, Tomáš Novotný, Robert Vlachovský, \\ Miroslav Krejčí
}

2nd Department of Surgery, Center for Vascular Disease, Faculty of Medicine, Masaryk University and St. Anne's University Hospital, Brno

\section{ARTICLE INFO}

Article history:

Submitted: 13. 4. 2020

Accepted: 10. 10. 2020

Available online: 30.11 .2020

Klíčová slova:

Akutní mezenteriální ischemie

Bolesti břicha

Descendentní hrudní aorta

Vlající aortální trombus

\section{SOUHRN}

Úvod: Floating thrombus of descending thoracic aorta (FTDTA) představuje přítomnost trombu v hrudní aortě, který vzniká z důvodu předchozího poranění aortální stěny (disekce, ateroskleróza, nádor nebo trauma) nebo ve zdravé hrudní aortě nejčastěji na podkladě trombofilie. Riziko FTDTA je dáno hlavně možností jeho periferní embolizace s rezultující viscerální nebo končetinovou ischemií.

Popis prípadu: Třiašedesátiletá žena s FTDTA a jeho periferní embolizací do arteria mesenterica superior (AMS) a arteria lienalis (AL) podstoupila embolektomii hrudní aorty a AMS po preparaci viscerálního segmentu břišní aorty cestou levostranné mediální viscerální rotace. V rámci second-look laparotomie byla provedena resekce ilea s end-to-end anastomózou a splenektomie. CTA hrudní a břišní aorty s odstupem 12 měsíců od operace prokazuje volný tepenný systém bez obrazu recidivy FTDTA. Třicet dva měsíců po provedení primární operační intervence je pacientka bez projevů malabsorpce v dobrém klinickém stavu.

Závěr: Akutní mezenteriální ischemie na podkladě embolizace FTDTA je vzácné onemocnění. Námi zvolený chirurgický přístup vycházel z dominující břišní symptomatologie u pacientky a suspekce na transmurální ischemii tenkého střeva. Dobrý klinický výsledek prokazuje validitu otevřeného cévněchirurgického přistupu v řešení uvedené diagnózy.

(c) 2020, ČKS.

\begin{abstract}
Introduction: Floating thrombus of the descending thoracic aorta (FTDTA) is defined as the presence of a thrombus inside the thoracic aorta, which is caused by an injury to the thoracic aortic wall (dissection, atherosclerosis, tumour, or trauma) or a thrombophilic state in the absence of a thoracic aortic wall injury. It is a rare condition, but can result in peripheral embolisation mainly into the limbs or visceral circulation. Report: A 63-year-old woman presented with signs of visceral embolisation into the superior mesenteric artery (SMA) and splenic artery (SA). Preoperative CT angiography (CTA) discovered the presence of FTDTA. She underwent emergent open embolectomy of the descending thoracic aorta and SMA done through a visceral segment of the abdominal aorta, reached by left-sided medial visceral rotation. During second-look laparotomy, she underwent splenectomy and ileal resection with end-to-end jejuno-ileal anastomosis. CTA of the thoracic and abdominal aorta performed 12 months after the initial operation showed no residual thrombus inside the aorta and patent peripheral vascular beds. Thirty-two months after the index operation, the patient shows no signs of malabsorption and is in good clinical condition.

Conclusion: Acute mesenteric ischemia resulting from embolisation of FTDTA is a rare disease. Our surgical approach was guided by the primary abdominal symptomatology of our patient and a clinical suspicion of transmural bowel ischemia being present. Our good clinical outcome confirms the viability of the open sur-

gical approach towards the therapy of complicated FTDTA.
\end{abstract}

Keywords:

Abdominal pain

Acute mesenteric ischemia

Descending thoracic aorta

Floating thrombus

Address: MUDr. Ernest Biroš, 2nd Department of Surgery, Center for Vascular Disease, Faculty of Medicine, Masaryk University and St. Anne's University Hospital, Pekařská 53, 65691 Brno, e-mail: ernest.biros@fnusa.cz DOI: 10.33678/cor.2020.091 


\section{Introduction}

Acute mesenteric ischemia (AMI) is caused by embolic occlusion of the SMA in $40-50 \%$ of cases; the heart is the most common source of emboli. ${ }^{1}$ Eighty percent of all peripheral and visceral emboli has a cardiac origin. FTDTA represents a clinical situation where a thrombus is present in the thoracic aorta, which itself is not affected by aneurysmal disease or extensive atherosclerosis. The first report describing the presence of mural thrombus in the thoracic aorta was published by Oliver in 1967. ${ }^{2}$ The incidence of FTDTA in the population based on autopsy findings is $0.45 \% .^{3}$ A previous impairment of the thoracic aortic wall (dissection, trauma, atherosclerosis, or tumour) or a patient's thrombophilic state (protein C or $S$ deficiency, essential thrombocythemia, antithrombin III deficiency) are the most common causes behind floating thrombus development. ${ }^{4}$ The risk of FTDTA comes from its propensity to embolise peripherally with resulting visceral or limb ischemia. The clinical presentation of FTDTA is mostly defined by signs and symptoms of its peripheral embolization. Efforts to discover the source of emboli usually result in FTDTA identification. The rapid evolution of imaging modalities (computed tomographic angiography [CTA], magnetic resonance angiography [MRA], trans-esophageal echocardiography [TEE]) during the last two decades has made FTDTA discovery more frequent.

Because FTDTA is a rare diagnosis with variable clinical presentation, its therapy is not firmly defined. Therapeutic options are anticoagulation medication alone, or an invasive intervention in the form of surgical thrombectomy, endarterectomy, or prosthetic replacement of the diseased segment of the thoracic aorta. Currently, invasive options include endovascular exclusion of FTDTA using a stent graft. Our case report describes the unconventional surgical therapy of FTDTA in a patient with its visceral embolization.

\section{Case report}

A 63-year-old woman presented with an 11-day history of abdominal pain, vomiting, diarrhoea, and an inability of oral intake. She had noticed blood in her stool for the previous two days. A diagnosis of AMI was presumed. She underwent CT angiography of the thoracic and abdominal aorta which discovered a floating thrombus in the descending thoracic aorta (FTDTA) (Fig. 1) with its embolization into the splenic artery (SA) and superior mesenteric artery (SMA) (Fig. 2). She exhibited signs of diffuse tenderness of her anterolateral abdominal wall, but without guarding. Her leukocyte count was 31.6 and C-reactive protein was 169 . She had a history of multiple sclerosis, which was in long-term remission and not being treated at the time. She had a history of deep vein thrombosis in her right lower extremity eight years prior, which had developed after knee arthroscopy. She had undergone a hysterectomy and bilateral adnexectomy because of an ovarian tumour, which was in long-term remission. She was a smoker. She was not taking any kind of antithrombotic therapy at the time of her clinical presentation.

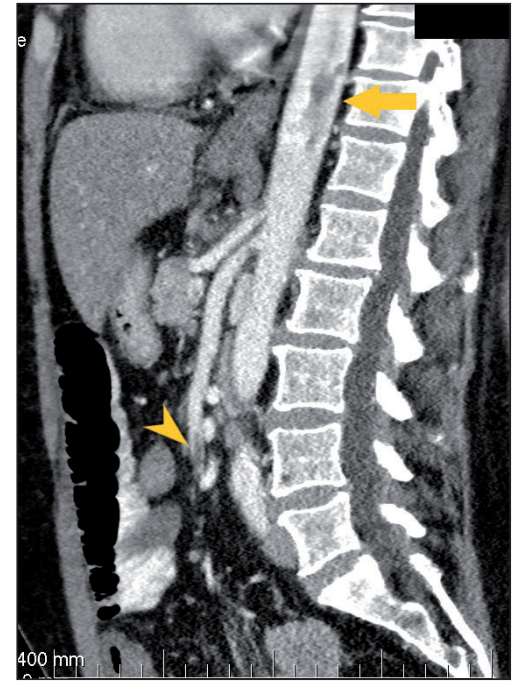

Fig. 1 - FTDTA (yellow arrow) with embolisation to the SMA (yellow arrowhead).

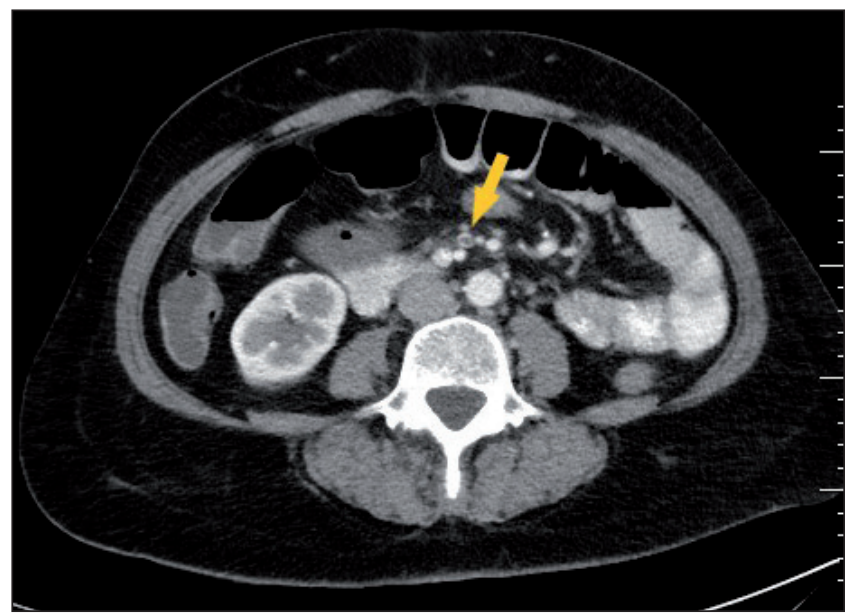

Fig. 2 - Fragment of FTDTA embolised into the SMA (yellow arrow).

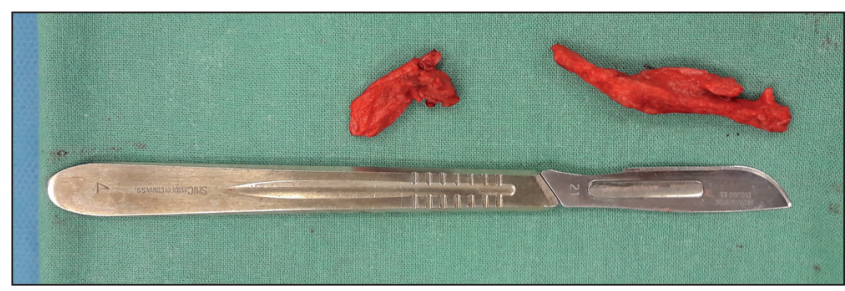

Fig. 3 - Retrieved organised thrombus from DTA.

The clinical presentation implied the presence of transmural bowel ischemia, so operative revision of the peritoneal cavity was indicated. The peritoneal cavity was approached through a midline laparotomy. We didn't find clearly demarcated ischemic bowels. Left-sided medial visceral rotation including the left kidney was done with the isolation of all visceral branches of the abdominal aorta. Diaphragmatic crura were divided, which helped in the isolation of the distal portion of the descending thoracic aorta. A longitudinal aortotomy made dorsally from all visceral aortic branches was used for indirect thrombectomy of the descending thoracic aorta (using a Foley catheter size 22) and all visceral aortic branches with removal of the embolus from the SMA (using Fogarty catheters). 


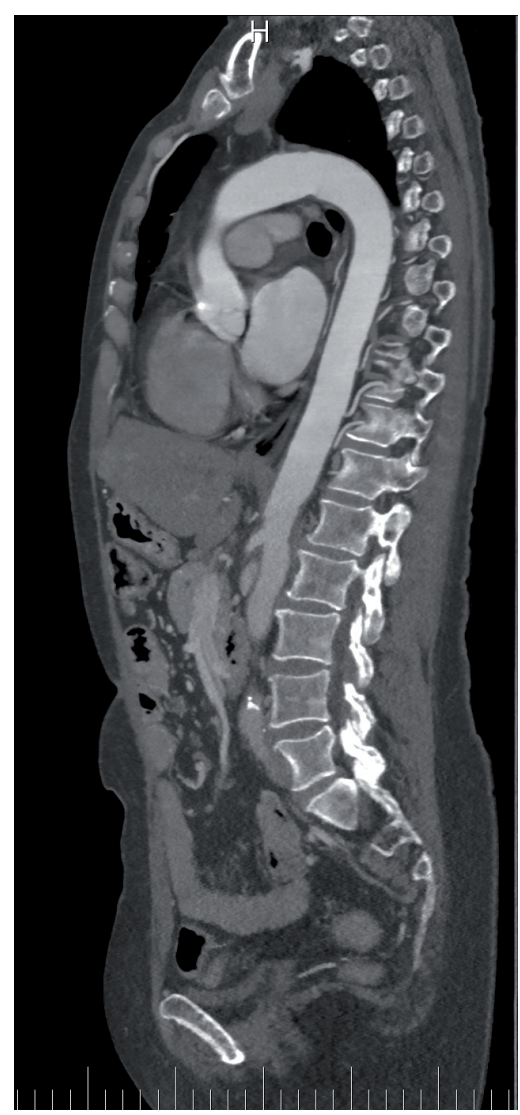

Fig. 4 - CTA done 12 months after the operation. No residual floating thrombus, patent SMA.

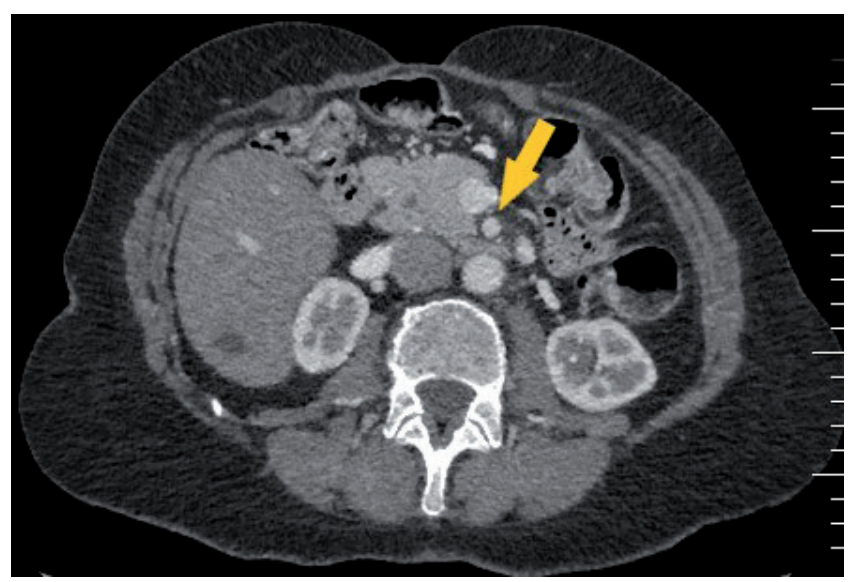

Fig. 5 - CTA done 12 months after the operation with patent SMA (yellow arrow).

The bowels were not resected and left for revision during second-look laparotomy. We did a splenectomy and resection of the ileum after 48 hours. Just $15 \mathrm{~cm}$ of terminal ileum was left and was used for the construction of an end-to-end jejuno-ileal anastomosis. Postoperatively, we dealt with a grade II surgical site infection affecting the whole length of the laparotomy. It was controlled successfully by systemic antibiotic therapy and local care. The patient suffered from malabsorption which has subsided only slowly. The patient was discharged on the 47th postoperative day with normal oral intake, normal bowel peristalsis, and a granulating laparotomy wound. Laboratory tests excluded a thrombophilic state as a cause of the patient's FTDTA. The retrieved material from DTA (Fig. 3) was $70 \times 8 \mathrm{~mm}$ in size and was histologically confirmed as an organised thrombus. Dual antiplatelet therapy (clopidogrel + acetylsalicylic acid) was initiated at the time of the patient's discharge.

The patient underwent $\mathrm{CT}$ angiography of the abdominal and thoracic aorta 12 months after the primary operation. This exam confirmed normal patency of the aorta and SMA (Figs 4 and 5). The exam also excluded residual thrombus or other pathology of the aortic wall, and confirmed the absence of abscess formation. The patient suffered from repeated bouts of temperature and an elevation of inflammatory markers during her follow-up which required antibiotic therapy despite undergoing proper vaccination. The suspected etiology is that the patient experienced an immunocompromised state after splenectomy. Signs and symptoms of malabsorption completely cleared up 18 months after the primary operation and the patient has started putting on weight. The laparotomy wound, after resolution of the surgical site infection, healed within three months of the patient's discharge. The patient is currently 32 months post operation, in a good clinical state and takes $100 \mathrm{mg}$ of acetylsalicylic acid daily.

\section{Discussion}

FTDTA is a rare diagnosis. A summary of all published cases of floating thrombus/primary mural aortic thrombus affecting all parts of the thoracic and abdominal aorta was released in 2014, describing 250 known cases. ${ }^{5}$ Approximately half of all cases were treated using invasive intervention. The low incidence of this diagnosis combined with variable clinical presentation makes it difficult to define a recommended treatment algorithm.

Anticoagulation therapy, surgical therapy, and endovascular therapy are the treatment options for FTDTA. ${ }^{5-7}$ Anticoagulation is the initial therapy for all patients with FTDTA until the next treatment step is decided. Unfractionated heparin is the first choice, which is exchanged for an oral anticoagulant (most frequently coumarin derivatives) in cases where invasive therapy is not indicated. An aortic thrombus persists in $26.4 \%$ of patients treated by anticoagulation therapy and in only $5.7 \%$ of patients treated by open surgical intervention. ${ }^{7}$ The risk of subsequent or recurrent embolisation is $25.7 \%$ in patients on anticoagulation therapy and $9.1 \%$ in patients after open surgical intervention. ${ }^{7}$ The risk of limb loss is higher for anticoagulation therapy $(9.0 \%)$ compared to open surgical intervention (2.0\%). The overall complication rate of anticoagulation therapy is $27.0 \%$, which is again a higher rate in comparison with open surgical therapy $(17.0 \%){ }^{7}$ These numbers show that anticoagulation therapy as a stand-alone therapy is inferior to open surgical intervention.

Surgical therapy can take the form of a thromboembolectomy, an endarterectomy of the aortic wall, or a prosthetic graft replacement of the aorta. Open surgical therapy is preferred when a floating thrombus is localised in the aortic arch and visceral segment of the abdominal aorta, or there is a suspicion of a primary aortic tumour as the cause of the floating thrombus. Our experience con- 
firms the effectiveness of the open surgical approach in the therapy of floating thrombus affecting the perivisceral segment of the abdominal aorta. The incidence of residual or recurrent thrombus after open surgical therapy is in the range of $0-32 \%$, depending on the literature source. $4,6,7$

Endovascular therapy of floating thrombus is an emerging modality first described by Criado et al. in $2004 .^{8}$ It uses stent grafts or, very rarely, closed-cell stents to cover a floating thrombus and exclude it from circulation. $4,5,6,8$ Floating thrombi localised in the DTA are suitable for endovascular therapy. It is generally recommended to achieve an overlap of at least $2 \mathrm{~cm}$ above the proximal extent and at least $2 \mathrm{~cm}$ below the distal extent of a floating thrombus. ${ }^{5,8}$ Fragmentation of a floating thrombus with distal embolization of its particles is a possible complication of endovascular therapy, but has not yet been described in the literature. Other forms of minimally invasive therapy, like catheter aspiration, systemic or catheter-directed thrombolysis, are not recommended because of the high risk of distal embolization and incomplete thrombus elimination. ${ }^{5,9}$

The above-mentioned therapeutic options can be combined so that we can devise a treatment plan which meets an individual patient's needs. Mixed/hybrid interventions which integrate stent grafting of floating thrombus with surgical or endovascular embolectomy of peripheral vascular beds have been described..$^{5,9}$

\section{Conclusions}

Floating thrombus of the descending thoracic aorta is a rare diagnosis. It needs to be considered in the differential diagnostic work-up of peripheral embolizations of non-cardiac origin. Under these circumstances, it represents a possible cause of acute mesenteric ischemia. CT angiography is the principal diagnostic study in these acute settings. The choice of therapy depends on the clinical state of the patient, morphology and localisation of the floating thrombus and its embolised fragments. Therapy is highly individualised. Our positive experience with open surgical thrombectomy of FTDTA and its embolised fragment in the SMA performed through visceral segment of the abdominal aorta confirms the place of open vascular surgery in floating thrombus therapy.

\section{Conflicts of interest}

The authors certify that there is no conflict of interest with any financial organization regarding the material discussed in the manuscript.

\section{Funding}

Supported by Ministry of Health of the Czech Republic, grant nr. 17-29701A.

\section{Authors' contributions}

Writing the article: Ernest Biroš

Conception and design: Ernest Biroš, Robert Staffa, Tomáš Novotný

Critical revision of the article: Ernest Biroš, Robert Staffa, Tomáš Novotný, Robert Vlachovský, Miroslav Krejčí

Final approval of the article: Ernest Biroš, Robert Staffa, Tomáš Novotný, Robert Vlachovský, Miroslav Krejčí Overall responsibility: Ernest Biroš

\section{References}

1. Oderich GS, editor. Mesenteric vascular disease: current therapy. New York: Springer, 2015:468.

2. Oliver DO. Embolism from mural thrombus in the thoracic aorta. Br Med J 1967;3:655-656.

3. Machleder HI, Takiff $\mathrm{H}$, Lois JF, Holburt E. Aortic mural thrombus: An occult source of arterial thromboembolism. J Vasc Surg 1986;4:473-478.

4. Tsilimparis N, Hanack U, Pisimisis G, et al. Thrombus in the non-aneurysmal, non-atherosclerotic descending thoracic aorta - an unusual source of arterial embolism. Eur J Vasc Endovasc Surg 2011;41:450-457.

5. Verma H, Meda N, Vora S, et al. Contemporary management of symptomatic primary aortic mural thrombus. J Vasc Surg 2014;60:1524-1534.

6. Meyermann K, Trani J, Caputo FJ, Lombardi JV. Descending thoracic aortic mural thrombus presentation and treatment strategies. J Vasc Surg 2017;66:931-936.

7. Fayad ZY, Semaan E, Fahoum B, et al. Aortic Mural Thrombus in the Normal or Minimally Atherosclerotic Aorta. Ann Vasc Surg 2013;27:282-290.

8. Criado E, Wall P, Lucas P, et al. Transesophageal echo-guided endovascular exclusion of thoracic aortic mobile thrombi. J Vasc Surg 2004;39:238-242.

9. Reber PU, Patel AG, Stauffer E, et al. Mural aortic thrombi: An important cause of peripheral embolization. J Vasc Surg 1999;30:1084-1089. 